\title{
Comparative performance of the mussels Perna perna and Perna viridis, cultivated at four different depths
}

\author{
Marielyn García ${ }^{1}$, César Lodeiros Seijo ${ }^{2,3 *}$, Luis Freites ${ }^{2}$, Henry Córdova ${ }^{l}$, \\ José Manuel Mazón Suástegui ${ }^{4}$, José Babarro
}

\author{
${ }^{1}$ Instituto Socialista de la Pesca y Acuicultura (INSOPESCA) \\ (Av. Lecuna Edif. Torre Este de Parque Central, piso 12,13 y 14 Conjunto Residencial Parque Central, Municipio Libertador Caracas- \\ Venezuela Zona Postal 1010) \\ ${ }^{2}$ Instituto Oceanográfico de Venezuela, Universidad de Oriente, Venezuela. \\ (Av. Universidad Cerro Colorado 245 Cumaná 6101 Estado Sucre, Venezuela) \\ ${ }^{3}$ Escuela Superior Politécnica del Litoral, Centro Nacional de Acuicultura e Investigaciones Marinas. \\ (km 30.5 Vía Perimetral Guayaquil, Ecuador) \\ ${ }^{4}$ Centro de Investigaciones Biológicas del Noroeste, Mexico. \\ (Av. Instituto Politécnico Nacional 195, Playa Palo de Santa Rita Sur; La Paz, B.C.S. México; C.P. 23096.) \\ ${ }^{5}$ Instituto de Investigaciones Marinas, C.S.I.C., Spain. \\ (Rúa de Eduardo Cabello, 6, CP 36208 Vigo, Pontevedra, España) \\ *Corresponding author: cesarlodeirosseijo@yahoo.es
}

\section{Abstract}

This study aims to evaluate the effect of environmental variability on the growth and survival of the subtropical and tropical mussels Perna perna and Perna viridis at four different culture depths in the Gulf of Cariaco during an annual cycle. Juveniles of $P$. perna $(39.1 \pm 1.88 \mathrm{~mm}$ in shell length) and $P$. viridis $(36.7 \pm 1.87 \mathrm{~mm})$ were sown on nylon ropes (3/4") and suspended from a raft at 1, 3, 6 and $9 \mathrm{~m}$ depths. Every six weeks, three replicates of each species were sampled (10 individuals per replicate) at each depth. Growth parameters were determined: mass and shell length, dry mass of soft tissues as well as fouling and survival rates. Temperature, transparency, chlorophyll $a$, oxygen, salinity and particulate organic and inorganic matter were recorded at each culture depth for the purpose of relating growth and survival to environmental change. The results show that the growth of both species was linked to the environment, especially with regard to the influence of the food and temperature. A period of stagnant growth of $P$. perna was associated with the higher temperature and lower phytoplankton biomass that is characteristic of the season with prevalent water column stratification (August-November 2007). By contrast, the growth of $P$. viridis did not stagnate, although it was gradual and relatively lower. At the end, $P$. perna achieved higher growth rates than $P$. viridis. Possible culture strategies to improve the production of both mussel species are discussed.

Descriptors: Culture depth, Growth, Fouling, Mussel, Upwelling period.

\section{Resumo}

O objetivo deste estudo foi avaliar o efeito da variabilidade ambiental sobre o crescimento e a sobrevivência de mexilhões subtropicais e tropicais Perna perna e Perna viridis em quatro profundidades de cultivo no Golfo de Cariaco, durante um ciclo anual. Juvenis de P. perna $(39,1 \pm 1,88 \mathrm{~mm}$ em comprimento de concha) e $P$. viridis $(36,7 \pm 1,87 \mathrm{~mm})$ foram semeados em cordas de nylon (3/4") e suspensos de uma jangada em 1, 3, 6 e 9 m de profundidade. A cada seis semanas, foram amostradas três repetições de cada espécie em cada profundidade. Os parâmetros de crescimento determinados foram: massa e comprimento de concha, massa seca dos tecidos moles, bem como incrustação (fouling) e as taxas de sobrevivência. Temperatura, transparência, clorofila $a$, oxigênio, salinidade e matéria orgânica e inorgânica particulada foram registados a cada profundidade de cultura com o objetivo de relacionar crescimento e sobrevivência às alterações ambientais. O crescimento de ambas as espécies foi analisado em relação ao ambiente, especialmente à influência dos alimentos e da temperatura. Um período de estagnação do crescimento de $P$. perna foi associado à maior temperatura e menor biomassa de fitoplâncton, características da temporada com prevalente estratificação da coluna de água (agosto a novembro de 2007). Em contraste, o crescimento do $P$. viridis não estagnou, embora tenha sido gradual e relativamente inferior. Ao final, P. perna alcançou taxas de crescimento mais elevadas do que $P$. viridis. Possíveis estratégias de cultivo para melhorar a produção de ambas as espécies de mexilhão são discutidas.

Descritores: Profundidade cultura, Crescimento, Incrustação, Mexilhão, Período de ressurgência. 


\section{INTRODUCTION}

The identification and selection of species suitable for aquaculture are key objectives of aquatic resources management. Currently there is a need to promote aquaculture as a food source, a genetic reserve and an additional mechanism to diminish production of commercial species by extractive fisheries.

Bivalve growth depends on the environmental quality of the cultivation area and, due to the rapid growth rates of mussels these organisms are well suited for culture on a commercial scale in subtidal biotopes (RIVONKER et al., 1993; RAJAGOPAL et al., 2006). BAUTISTA (1989) has indicated that mussel growth is a function of a number of environmental parameters, mainly food and temperature. The environment influences the somatic and reproductive tissue growth of marine bivalves both directly and indirectly (GRIFFITHS; GRIFFITHS, 1987; LODEIROS; HIMMELMAM, 2000). The availability and quality of food can be considered an important factor since it affects physiological processes linked to growth (BAYNE; NEWEL, 1983). Suspended food particles for bivalves vary in quality and quantity and, in general, are composed of seston which itself is a complex mixture of pelagic organisms and suspended detritus (NAVARRO; THOMPSON, 1995; CRANFORD; HILL, 1999; HAWKINS et al., 2001). Additionally, the high selection capacity for particle quality might be independent of phytoplankton abundance and may have also a direct effect on growth. Selection processes of high-quality particles have already been reported in other bivalves, particularly when seston is abundant (VELASCO; NAVARRO, 2002; CARMICHAEL et al., 2004).

In Venezuela, $P$. perna is one of the country's fishery resources of greatest potential for large-scale cultivation, since it has a rapid pace of growth, achieving high rates with sizes up to $90 \mathrm{~mm}$ in less than a year under suspended culture systems (PRIETO et al., 1999).

In many tropical countries, $P$. viridis shows high performance and growth under culture conditions. It is the tropical mussel species with highest worldwide production, particularly in Asia and adjacent areas (GALLARDO et al., 1992; SREENIVASAN et al., 1989). In coastal areas of India, this mussel is considered to be suitable for culturing purposes on a commercial scale (RIVONKER et al., 1993; RAJAGOPAL et al., 1998), in which animals may grow up to $79.8 \mathrm{~mm}$ in 11 months (SREENIVASAN et al., 1989). Commercial cultivation of the mussel P. viridis was started in late 1995 at Anthakaranazhi (Alleppey district) by local fishermen on long lines. This type of commercial activity along the southwest coast of India has expanded greatly since 1997 in different parts of the country (APPUKUTTAN et al., 2001) and cultured mussel production attained around 800 tons in 2002 and 12000 tons by the year 2007-2008 (NAIR; APPUKUTTAN, 2003).

With regard to the influence that environmental changes may have on both species of mussels in the Caribbean Sea, it has been shown that the performance of P. perna depends physiologically on endogenous variability such as reproduction (ARRIECHE et al., 2002). The interaction with the environment is also important, depending mainly on the food availability periods generated by the upwelling and stratification of the water column that occur annually in northeastern Venezuela. With respect to P. viridis, SEGNINI et al. (1998) and SEGNINI (2003) have shown that it is a species rather tolerant to variations in temperature and salinity (thermohaline species), environmental factors that are crucial for population dynamics. On the one hand, VIÑOLES (2000) found that $P$. viridis has a higher instantaneous growth at relatively high temperatures $\left(28^{\circ} \mathrm{C}\right)$ while, on the other, VIÑOLES et al. (2000) demonstrated that food is an important element that influences growth.

Previous studies on the growth of P. perna and $P$. viridis, cultivated at different depths $(4,8$ and $16 \mathrm{~m})$ under suspended culture in the Caribbean Sea, showed that $P$. perna grows bigger than $P$. viridis (ACOSTA et al., 2009). However, these authors only studied growth during the period mainly characterized by stratification of the seawater column (August-February), ignoring the upwelling period (March-July).

Another aspect that could affect potentially the production levels of mussel culture is the fixation of fouling organisms. Several studies on bivalves demonstrate reduced growth and survival as a result of depletion of food resources (THOMPSON; MACDONALD, 1991, ELLIS et al., 2002; WAITE et al., 2005; DRAPEAU et al., 2006), because many fouling organisms are suspension feeders and may compete with the cultured bivalves for food resources. For example, the tunicates Styela clava and Ciona intestinalis competed for space and food with Mytilus edulis, potentially decreasing mussel productivity (THOMPSON; MACNAIR, 2004; MACNAIR, 2005).

In NE Venezuela, upwelling processes are caused by periodic trade winds in the first half of the year 
(MILOSLAVICH; KLEIN, 2008). As a result, primary productivity increases and can reach values above 231 $\mathrm{g}$ of $\mathrm{C} \mathrm{m}^{-3}$ (MANDELLI; FERRÁZ-REYES, 1982). During this period, water temperatures range between 21 and $25^{\circ} \mathrm{C}$ and phytoplankton is essentially distributed in the superficial layers of the water column, the highest density occurring in the upper $20 \mathrm{~m}\left(\max .300\right.$ cells $\left.\mathrm{mL}^{-1}\right)$. Occasionally, density may increase up to 2600 cells $\mathrm{mL}^{-1}$, with the highest concentration of chlorophyll $a\left(8 \mathrm{mg} \mathrm{m}^{3}\right)$ at the surface (VARELA et al., 2003). In contrast, the period of relaxation of coastal upwelling (August-November) is characterized by stratification of the seawater column, low primary productivity and higher temperatures between 26 and $29{ }^{\circ} \mathrm{C}$ (MANDELLI; FERRÁZ-REYES, 1982; FERRÁZ-REYES, 1989).

In order to understand how exogenous factors can affect the growth of both mussel species distributed in NE Venezuela (RYLANDER et al., 1996), we aimed to study the effect of the environment on the growth of P. perna (subtropical) and $P$. viridis (tropical) in the Gulf of Cariaco over one year. We further considered the spatial variation in environmental variables through the water column in order to derive strategies of suspended culture for efficient management of these natural resources.

\section{MATERIAL AND METHODS}

\section{STUDY AREA}

Mussel seeds were collected from natural beds in Guaca, Sucre state, Venezuela ( $10^{\circ} 39^{\prime} 39.06^{\prime \prime}$ N; 63 $25^{\prime}$ $\left.24.09^{\prime \prime} \mathrm{W}\right)$ and transplanted to the raft culture of mussels located at Fragata bay, Gulf of Cariaco $\left(10^{\circ} 27^{\prime} 6.71\right.$ ' N; $\left.65^{\circ} 56^{\prime} 41.19^{\prime \prime} \mathrm{W}\right)$.

\section{EXPERIMENTAL CULTURE}

Mussel seed of both species were separated and maintained for 24 hours in seawater in suspended plastic containers at $3 \mathrm{~m}$ depth at the Fragata site. A uniform size was selected, $39.1 \pm 1.88 \mathrm{~mm}$ for P. perna and $36.7 \pm 1.87$ $\mathrm{mm}$ for $P$. viridis. Seed was sown on nylon ropes (3/4") at a density of $1 \mathrm{~kg}$ per meter of rope (26 and 29 individuals for $P$. perna and P. viridis, respectively), for each water column depth selected in the study $(1,3,6$ and $9 \mathrm{~m})$. Seeds were hung on the rope using a mesh which was removed after 15 days, once the natural attachment of the mussels was confirmed. Rafts were used for cultivation. Seven ropes per mussel species were hung from each raft, giving a total of 21 replicates per species, including the four water column depths $(1,3,6$ and $9 \mathrm{~m})$ on each rope. The experiment was conducted from May 2007 to March 2008, inclusive. Sampling was performed every 6 weeks on 3 ropes of each species (one rope of each raft) for the respective analyses.

Ten individuals were sampled at random for each replicate per water column depth and mussel species. The animals were carefully cleaned of shell fouling, and the soft tissues were removed from each mussel using dissecting equipment to obtain the mass of fouling, shell, gonad, adductor muscle and the remaining somatic tissues. These components were dehydrated in an oven $\left(60^{\circ} \mathrm{C}\right.$ for $48 \mathrm{~h}$ ) to obtain dry weight values with an error of 0.001 g. Shell length (Lt) (from the hinge to the ventral edge), height $(\mathrm{H})$ (maximum perpendicular distance, that is, the length in the ventral dorsal direction), and the width (W) (distance between the maximum convexity of the valves) were determined. These measurements were made with a digital caliper ( $0.01 \mathrm{~mm}$ accuracy).

The formula used to calculate growth increments was the following: $\left(\left(\chi_{2}-\chi_{1} / \chi_{1}\right) /\right.$ days $) \times 100$, where " $\chi_{2}$ " and " $\chi_{1}$ " denote two continuous samplings and "Days" is the number of days of that sampling interval.

\section{SURVIVAL}

An amount of live mussels from each of the three replicates at each water column depth $(1,3,6$ and $9 \mathrm{~m})$ and sampling time was used to determine survival rates with regard to the initial number of organisms seeded, followed by an average of the three replicates for each water depth. This procedure was performed for each mussel species cultured.

\section{ENVIRONMENTAL FACTORS}

Water temperature was monitored continuously for each water depth using electronic thermographs (SealogVemco) with a $30 \mathrm{~min}$ sampling frequency. The data were downloaded to a computer half way through and at the end of the sampling time. Water transparency was measured weekly with a Secchi disk.

For oxygen measurements, water samples were carefully taken from each depth using a Niskin bottle to avoid any trapping of air bubbles. Isothermal containers were used to transport the bottles to the laboratory for quantification by the Winkler method within two hours. Salinity was determined with a refractometer (Atago, precision1 UPS). 
The water samples used for the determination of phytoplankton biomass and total seston were transferred to an opaque plastic container and transported to the laboratory. Two replicates of $1 \mathrm{~L}$ were used to determine chlorophyll $a$ and total particulate matter for each water depth. The samples were pre-filtered $(153 \mu \mathrm{m})$ to remove large particulate matter and zooplankton. Sea-water samples were filtered on prewashed $\left(450^{\circ} \mathrm{C}\right.$ for $\left.4 \mathrm{~h}\right)$ and weighed $\mathrm{GF} / \mathrm{F} 0.7 \mu \mathrm{m}$ filters and then rinsed with isotonic ammonium formate $(0.5 \mathrm{M})$. Total seston, including its inorganic and organic fractions, was obtained by the gravimetric method after combustion in a muffle $\left(450^{\circ} \mathrm{C}, 4 \mathrm{~h}\right)$. Phytoplankton abundance was estimated by chlorophyll $a$ measured photometrically (STRICKLAND; PARSON, 1972).

To evaluate the effect of shells' biofouling on growth and survival, the dry mass $\left(60^{\circ} \mathrm{C} / 48 \mathrm{~h}\right)$ of fouling organisms on each individual shell of each replicate was quantified.

\section{STATISTICAL ANALYSES}

The growth and survival of mussels, at end of the experiment, were analyzed using a one-way ANOVA after the verification of the assumptions of normality and homogeneity of variances. If any of these factors showed a significant effect $(p<0.05)$, a Duncan post-hoc analysis was applied ( $p<0.05$ ) (SOKAL; ROHLF, 1979). Also, biometric data obtained from the last sample of the study period were analyzed using two-way ANOVA, where biometric parameters were considered as dependent variables and mussel species and culture depths were taken as fixed factors.

Multiple regression analysis ("Stepwise") was used to explore interactions between survival, growth of each mussel species and culture depth and related environment variability. Independent variables (environmental factors) were the average of the measurements between each sampling period. The growths of each body compartment studied were considered as dependent variables. In this analysis, the culture depths were assigned values of 1 (1 m), 2 (3 m), 3 (6 m), 4 (9 m).

The biometric data of mussels were transformed into $\log _{10}$ and survival percentages into arcsine (SOKAL; ROHLF, 1979).

\section{RESULTS}

\section{ENVIRONMENTAL FACTORS}

Overall, POM curves showed similar trends increasing over the experimental period (Figure 1A) and reaching their highest values in March $(8.6 \pm 0.70$ at $3 \mathrm{~m}, 8.4 \pm 0.73$ at $6 \mathrm{~m}$ and $9.7 \pm 0.49 \mathrm{mg} \mathrm{L}^{-1}$ at $9 \mathrm{~m}$ ), with the exception of $1 \mathrm{~m}$ depth where was highest reported POM value was observed in December $\left(8.0 \pm 0.59 \mathrm{mg} \mathrm{L}^{-1}\right)$. The average POM concentrations were $4.9 \mathrm{mg} \mathrm{L}^{-1}$ at $1 \mathrm{~m}$ depth, 5.1 $\mathrm{mg} \mathrm{L}^{-1}$ at $3 \mathrm{~m}, 5.6 \mathrm{mg} \mathrm{L}^{-1}$ at $6 \mathrm{~m}$ and $6.2 \mathrm{mg} \mathrm{L}^{-1}$ at $9 \mathrm{~m}$. A similar trend was observed for PIM concentrations (Figure 1B), with the highest values at the end of the experimental period at all depths, with the exception of $9 \mathrm{~m}$ depth that showed the highest values in December $\left(16.2 \mathrm{mg} \mathrm{L}^{-1}\right)$.

Temperature ranged between $28.4{ }^{\circ} \mathrm{C}$ at $1 \mathrm{~m}$ in August 2007 and $21.3^{\circ} \mathrm{C}$ at $9 \mathrm{~m}$ in March 2008 (Figure 1C). As a general pattern, temperature increased in June 2007, decreased in July and later increased in August and maintained values over $27^{\circ} \mathrm{C}$ until early November 2007. Then, temperature decreased sharply until March which represented the lowest values of the study, with mean values of $22.4 \pm 1.15^{\circ} \mathrm{C}$ ).

Phytoplankton biomass expressed as chlorophyll $a$ showed an inverse trend to temperature (Figure 1D), presenting an initial period (May-June 2007) with values ranging between 5 and $8 \mu \mathrm{g} \mathrm{L}^{-1}$, then a period with a lower concentration of chlorophyll $a$ was observed between August and November 2007( $\left.>2 \mu \mathrm{g} \mathrm{L}^{-1}\right)$. From December 2007 to March 2008 chlorophyll $a$ increased continuously up to maximum values of $12.9 \pm 0.48 \mu \mathrm{g} \mathrm{L}^{-1}$.

Oxygen showed a similar trend to temperature but inverse to the phytoplankton biomass throughout the culture period (Figure 1E) with values ranging from 3.2 to $6.2 \mathrm{mg} \mathrm{L}^{-1}$. The lowest values were measured in June 2007 (3.41 $\mathrm{mg} \mathrm{L}^{-1}$ ) and January $2008\left(3.94 \mathrm{mg} \mathrm{L}^{-1}\right)$. The highest concentrations of dissolved oxygen were measured from September to December 2007, with the maximum average value being recorded in September 2007 (5.96 $\left.\mathrm{mg} \mathrm{L}^{-1}\right)$.

Salinity values varied between $36.2 \mathrm{PSU}$ at $1 \mathrm{~m}$ water depth in September (coinciding with the rainy season), and 38.6 PSU at $9 \mathrm{~m}$ depth in June (Figure 1F). Higher salinities were found in June and early August 2007, with maximum mean values of four depths recorded in June 2007 (38.25 PSU) and December 2007 (37.75 PSU), followed by a period when intermediate salinity values were observed between February and March 2008 with a mean of 36.98 PSU).

Transparency of the water column showed minimum values of $2.30 \mathrm{~m}$ in July 2007 and early February 2008 (Figure $1 \mathrm{G})$, and the highest values $(<12 \mathrm{~m})$ in June and August 2007. Water column showed also middles transparency values in late May, September and early October 2007 (8.20, 8.40 and $8.45 \mathrm{~m}$ respectively). 

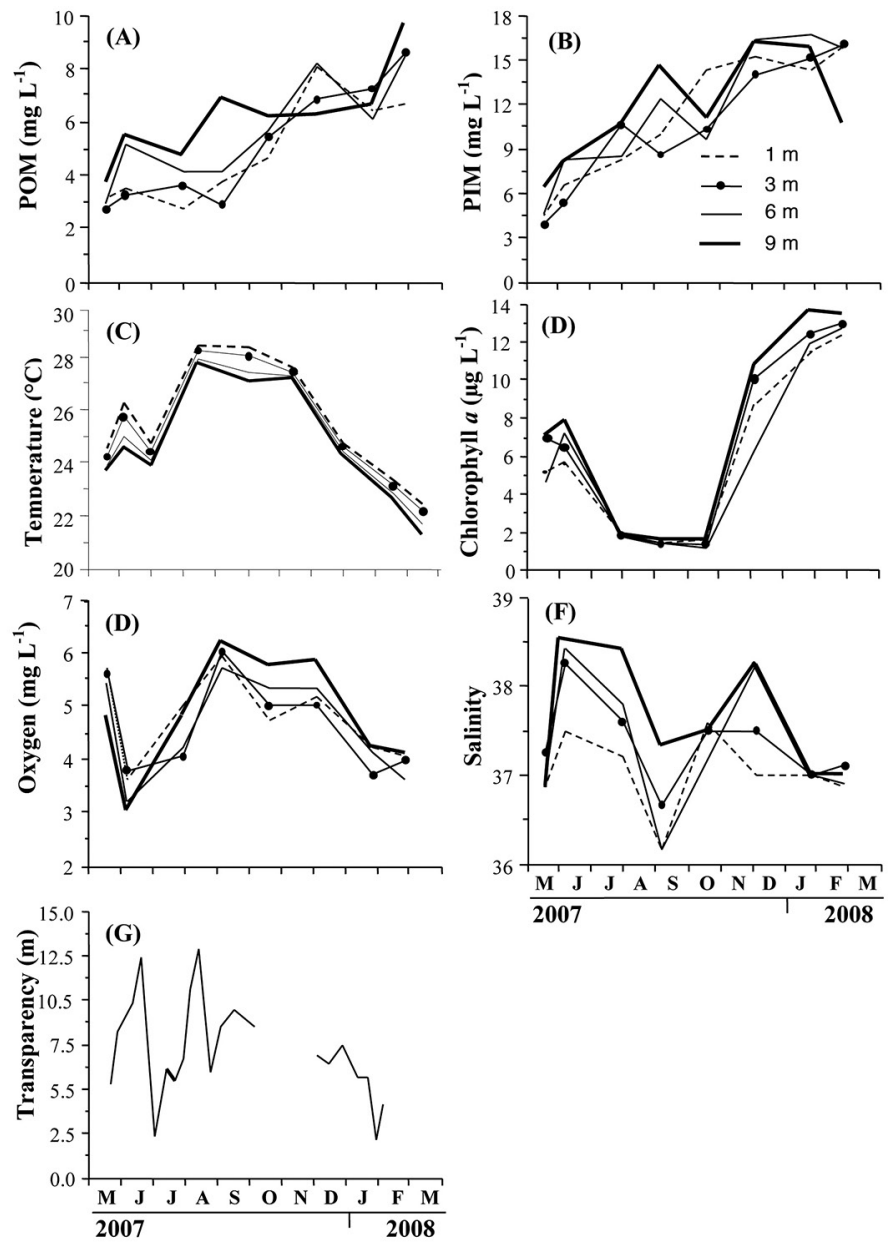

Figure 1. Variation of environmental variables: A) POM; B) PIM; C) Chlorophyll $a$; D) Oxygen; E) Temperature; F) Salinity and G) transparency, at the different depths studied.

\section{Biofouling}

Biofouling mass and other material deposited on the shell of mussels were evident only from early September 2007 (Figure 2A-D). A relative greater presence of these organisms was observed in $P$. perna with maximum values of $15.0 \pm 0.80 \mathrm{~g}$ at $6 \mathrm{~m}$ depth (Figure 2C), higher than $P$. viridis (at $3 \mathrm{~m}: 9.8 \pm 2.17 \mathrm{~g}$ ). In P. perna, significant differences $(p<0.05)$ between depths were observed, with water depths of $1 \mathrm{~m}(6.5 \pm 4.23 \mathrm{~g})$ and $9 \mathrm{~m}(7.0 \pm 1.99$ g) representing the lowest values (Duncan, $p<0.05$ ) as compared to $3 \mathrm{~m}(12.7 \pm 2.39 \mathrm{~g})$ and $6 \mathrm{~m}$ water depth $(15.0 \pm 0.80 \mathrm{~g})$. In contrast, $P$. viridis showed no significant differences in biofouling between water depths $(p>0.05)$.

\section{SHELL LENGTH}

In general, at the end of the study period, two-way ANOVA analysis showed that mussel species and depth culture had a significant effect on the growth of shell length ( $p>0.05$; Table 1), while their interaction was not significant.

Within a seasonal perspective, growth of P. perna was almost interrupted at all water depths from September to early December 2007 (Figure 3A-D), after which growth rates increased more steeply until the end of the study. In contrast, the growth of $P$. viridis was continuous at all depths. Nevertheless, P. perna showed the highest growth rates since at the end of the study period this species reached maximum lengths of $78.2 \mathrm{~mm}$ at $6 \mathrm{~m}$ (Figure 3C), whereas $P$. viridis only attained $69.9 \mathrm{~mm}$ at $9 \mathrm{~m}$ (Figure $3 \mathrm{D})$.

The final length obtained by $P$. perna individuals at $6 \mathrm{~m}$ and $9 \mathrm{~m}$ depths was $78.2 \pm 1.48 \mathrm{~mm}$ and $77.8 \pm 0.34$ $\mathrm{mm}$ (Figure 3C, D) and they were significantly greater (ANOVA, Duncan, $p<0.05$ ) than at $1 \mathrm{~m}$ depth 
Fouling (g)
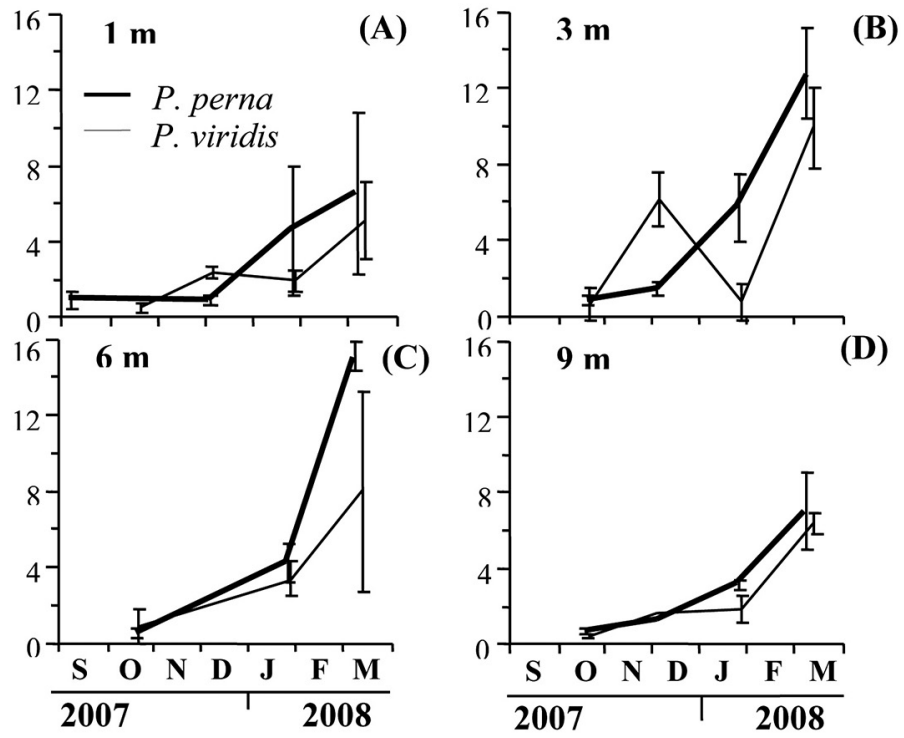

Figure 2. Variation of the dry mass of fouling fixed on P. perna and P. viridis grown at $1 \mathrm{~m}(\mathrm{~A}), 3 \mathrm{~m}(\mathrm{~B}), 6 \mathrm{~m}$ (C) and $9 \mathrm{~m}$ (D).

Table 1. Results of two-way ANOVA analysis evaluating the effects of 'species' (P. perna and P. viridis) and 'depth culture' (1, 3,6 and $9 \mathrm{~m}$ ) factors on the growth (log transformation of tissue dry mass, shell length and dry mass, and arcsine transformation of survival).

\begin{tabular}{|c|c|c|c|c|}
\hline Variable & Source of variation & d.f. & Sum of squares & F-ratio \\
\hline \multirow{4}{*}{ Shell mass } & A: Species & 1 & 0.214 & $36.543 * * *$ \\
\hline & B: Depth culture & 3 & 0.030 & $5.199 *$ \\
\hline & Interaction: $\mathrm{A} * \mathrm{~B}$ & 3 & 0.006 & $0.985 \mathrm{NS}$ \\
\hline & Error & 16 & 0.094 & \\
\hline \multirow{4}{*}{ Shell length } & A: Species & 1 & 0.005 & $16.063 * * *$ \\
\hline & B: Depth culture & 3 & 0.031 & $30.887 * * *$ \\
\hline & Interaction: $\mathrm{A} * \mathrm{~B}$ & 3 & 0.002 & $2.086 \mathrm{NS}$ \\
\hline & Error & 16 & 0.005 & \\
\hline \multirow{4}{*}{ Tissue mass } & A: Species & 1 & 0.337 & $132.022 * * *$ \\
\hline & B: Depth culture & 3 & 0.602 & $78.499 * * *$ \\
\hline & Interaction: $\mathrm{A} * \mathrm{~B}$ & 3 & 0.120 & $15.701 * * *$ \\
\hline & Error & 16 & 0.041 & \\
\hline \multirow{4}{*}{ Survival } & A: Species & 1 & 145.672 & $44.155^{* * *}$ \\
\hline & B: Depth culture & 3 & 3672.035 & $14.737 * * *$ \\
\hline & Interaction: $\mathrm{A} * \mathrm{~B}$ & 3 & 340.316 & $3.057^{*}$ \\
\hline & Error & 16 & 678.460 & \\
\hline
\end{tabular}

NS, not significant; ${ }^{*} p>0.05 ; * * p>0.01 ; * * * p>0.001$.

$(71.6 \pm 4.13 \mathrm{~mm})$. In contrast, $P$. viridis grew up to $58.2 \pm 3.97 \mathrm{~mm}$ at $1 \mathrm{~m}$ depth (Figure $3 \mathrm{~A}$ ), representing a significantly lower growth performance (ANOVA, Duncan, $p<0.05)$ compared to that at other water depths. The greatest length was observed at $9 \mathrm{~m}$ $(69.9 \pm 1.47 \mathrm{~mm})$.

\section{SHELL MASS}

Once again, at the end of the study period, two-way ANOVA analysis showed that mussel species and depth culture had a significant effect on the growth of shell mass ( $p>0.05$ and $p>0.01$ respectively; Table 1$)$, while their interaction was not significant. 


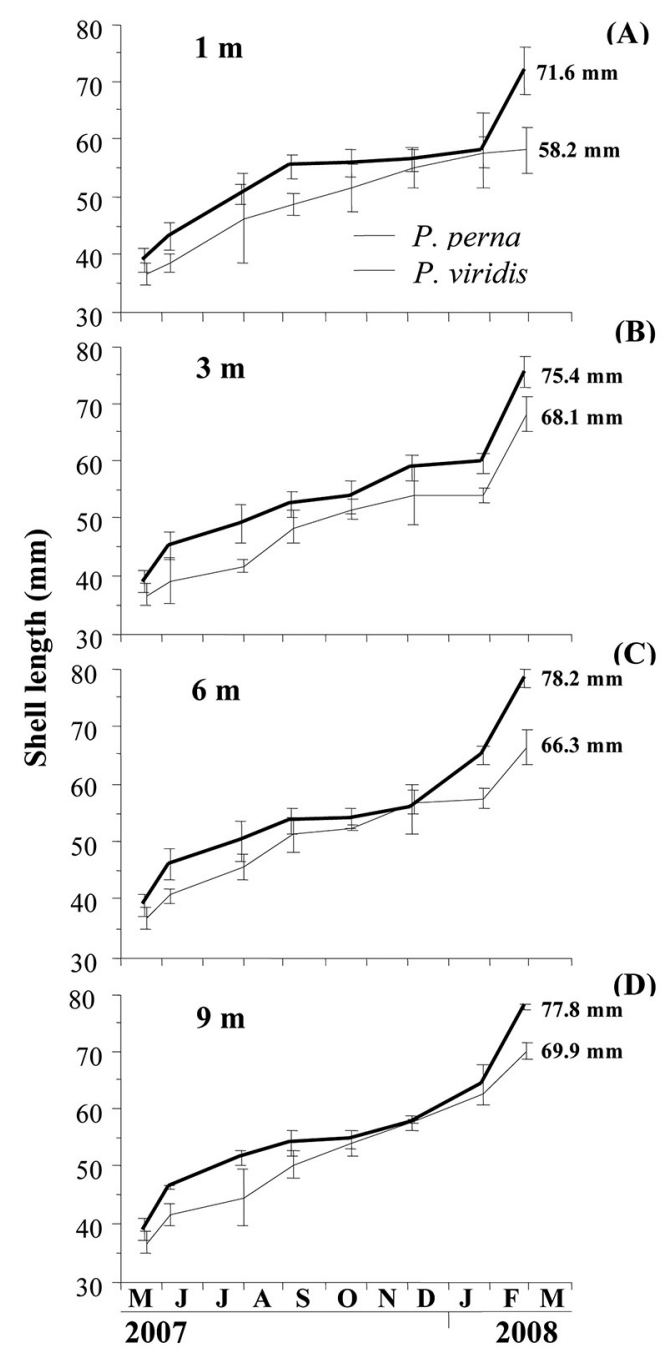

Figure 3. Variation of the shell length of $P$. perna and $P$. viridis grown at $1 \mathrm{~m}(\mathrm{~A}), 3 \mathrm{~m}(\mathrm{~B}), 6 \mathrm{~m}(\mathrm{C})$ and $9 \mathrm{~m}(\mathrm{D})$.

The shell mass of both species showed similar trends throughout the cultivation period, with a progressive growth until October 2007 for $P$. perna and January 2008 for $P$. viridis (Figure 4A-D). P. perna showed a greater increase in the growth curve from October 2007 becoming more pronounced from late January 2008 until the end of the study. For $P$. viridis, this change in the slope of the growth rate occurred later (at the end of January 2008). At the end of the study, the average variation for the four depths of the species comparison (ANOVA, Duncan, $p<0.05)$ was higher for P. perna $(21.7 \mathrm{~g})$ than P. viridis (14.9 g).

Shell mass showed variability between water depths. At the end of the study, P. perna showed a lower shell mass at $1 \mathrm{~m}(15.7 \pm 7.10 \mathrm{~g})$ and $9 \mathrm{~m}(20.2 \pm 1.95 \mathrm{~g})$, compared to 3

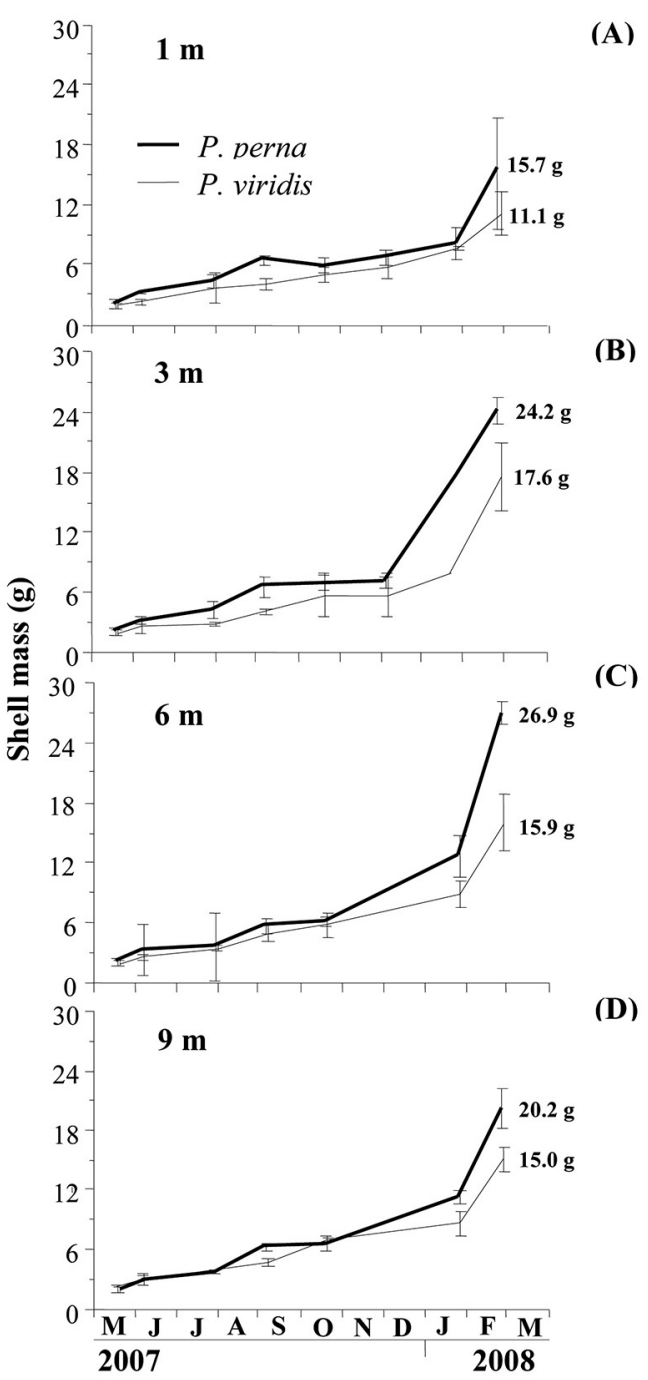

Figure 4. Variation of shell dry mass of $P$. perna and $P$. viridis grown at $1 \mathrm{~m}(\mathrm{~A}), 3 \mathrm{~m}(\mathrm{~B}), 6 \mathrm{~m}(\mathrm{C})$ and $9 \mathrm{~m}(\mathrm{D})$.

$\mathrm{m}(24.2 \pm 1.36 \mathrm{~g})$ and $6 \mathrm{~m}(27.0 \pm 7.10 \mathrm{~g})$ (ANOVA, Duncan, $p<0.05)$. $P$. viridis showed no significant differences in shell mass for different depths (ANOVA, Duncan, $p>0.05$ ), which were within the range of $11.1 \pm 2.11 \mathrm{~g}$ at 1 $\mathrm{m}$ and $17.6 \pm 3.41 \mathrm{~g}$ at $3 \mathrm{~m}$

\section{TISSUE MASS}

Two-way ANOVA analysis showed that at the end of the study period mussel species and depth culture and their interaction had a significant effect on tissue mass ( $p>0.05$; Table 1), a result that can be attributed to the fact that $P$. perna reached greater tissue masses than $P$. viridis and by the direct relationship between the tissue mass of P. perna and the depth of culture. 
As a general pattern, growth of tissue dry mass showed a similar trend for both species, with an increase until July 2007 , followed by a cessation or decrease in October, a moderate increase until December ( 1 and $3 \mathrm{~m}$ depth) or October (6 and $9 \mathrm{~m}$ depth), and finally a new increase as from January until maximum values were reached in March 2008. P. perna obtained greater masses at 6 and $9 \mathrm{~m} \mathrm{(5.17}$ and $7.59 \mathrm{~g}$, respectively) while $P$. viridis attained them at 3 and $9 \mathrm{~m}$ (2.30 and $2.41 \mathrm{~g}$, respectively) (Figure 5B, C, D).

In general, $P$. perna showed a greater increase in the growth curve from October 2007 which became more pronounced from late January 2008 until the end of the study. For $P$. viridis, this change in the slope of the growth rate occurred later (at the end of January 2008). From June until October no significant differences were observed between the growth values of the two mussel species, while at the end of the study the tissue dry mass of $P$. perna was significantly greater than that of $P$. viridis $(p<0.05)$ at the four culture depths studied.

\section{SURVIVAL}

In general, at the end of the study period, two-way ANOVA analysis showed that mussel species and depth culture had a significant effect on increase of survival $(p>0.05)$ and their interaction $(p>0.05$; Table 1$)$, which could be attributed to the greater survival observed by $P$. viridis than $P$. perna at the end of the study, at almost all the depths, except for those grown at $6 \mathrm{~m}$.

Survival was highly variable between replicates, as is evidenced by the high rates of dispersion in each sample for both species (Figure 6A-D). However, at the end of the study period highly significant differences in survival were observed between the two mussel species $(p<0.05)$ with higher values for $P$. viridis (51 and 91\%) (Figure 6A-D) than for P. perna (22 and 53\%). This was most likely due to the abrupt survival decreases recorded at the beginning of the study among P. perna (43-68\%), as compared to the much lower ones observed for $P$. viridis (87-98\%). For each mussel species, variability did not allow significant differences $(p>0.05)$ between depths for $P$. perna to be established, in contrast to $P$. viridis for which differences were observed $(p<0.05)$.

\section{RELATIONSHIP BETWEEN GROWTH, CULTURE}

\section{DEPTH AND RELATED ENVIRONMENTAL FACTORS}

In general, the stepwise multiple regression analysis showed that during the experiment, POM participated

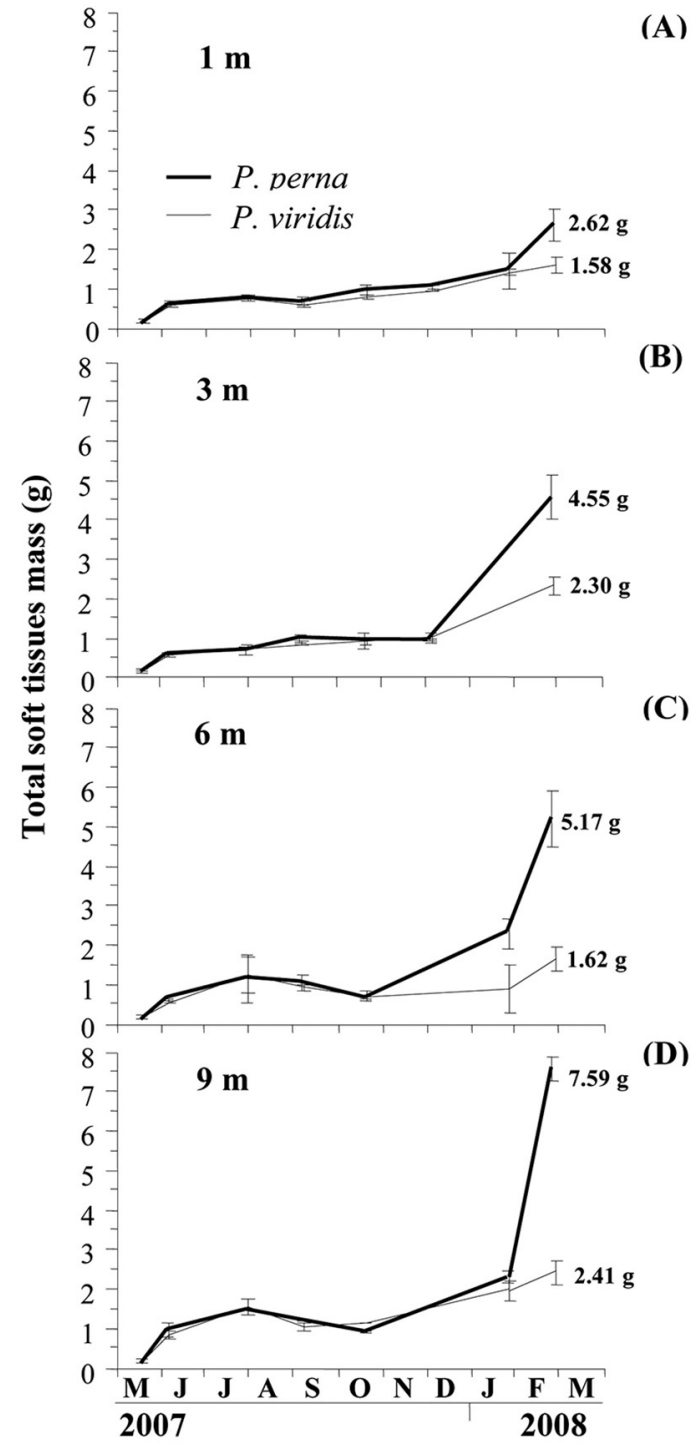

Figure 5. Variation of soft tissues dry mass of $P$. perna and $P$. viridis grown at $1 \mathrm{~m}(\mathrm{~A}), 3 \mathrm{~m}(\mathrm{~B}), 6 \mathrm{~m}(\mathrm{C})$ and $9 \mathrm{~m}(\mathrm{D})$.

positively and significantly $(p<0.01)$ in the explanation of the variance observed in almost all the biometric parameters (mass and length shell and tissue mass) of $P$. perna and $P$. viridis (Tables 2 and 3), their percentages lying between 50.3 and $59.2 \%$ for P. perna, and 42.2 and $73.2 \%$ for $P$. viridis. Temperature participated inversely and significantly $(p<0.01)$, increasing the percentages of explanation for the biometric parameters of $P$. perna and $P$. viridis up to values over 60 and $57 \%$, respectively. In $P$. perna, survival variance was explained positively and significantly $(p<0.05)$ by the participation of oxygen and interaction between culture depth and chlorophyll $a$ and inversely by PIM, attaining a percentage of explanation of $57.5 \%$, while in $P$. viridis 


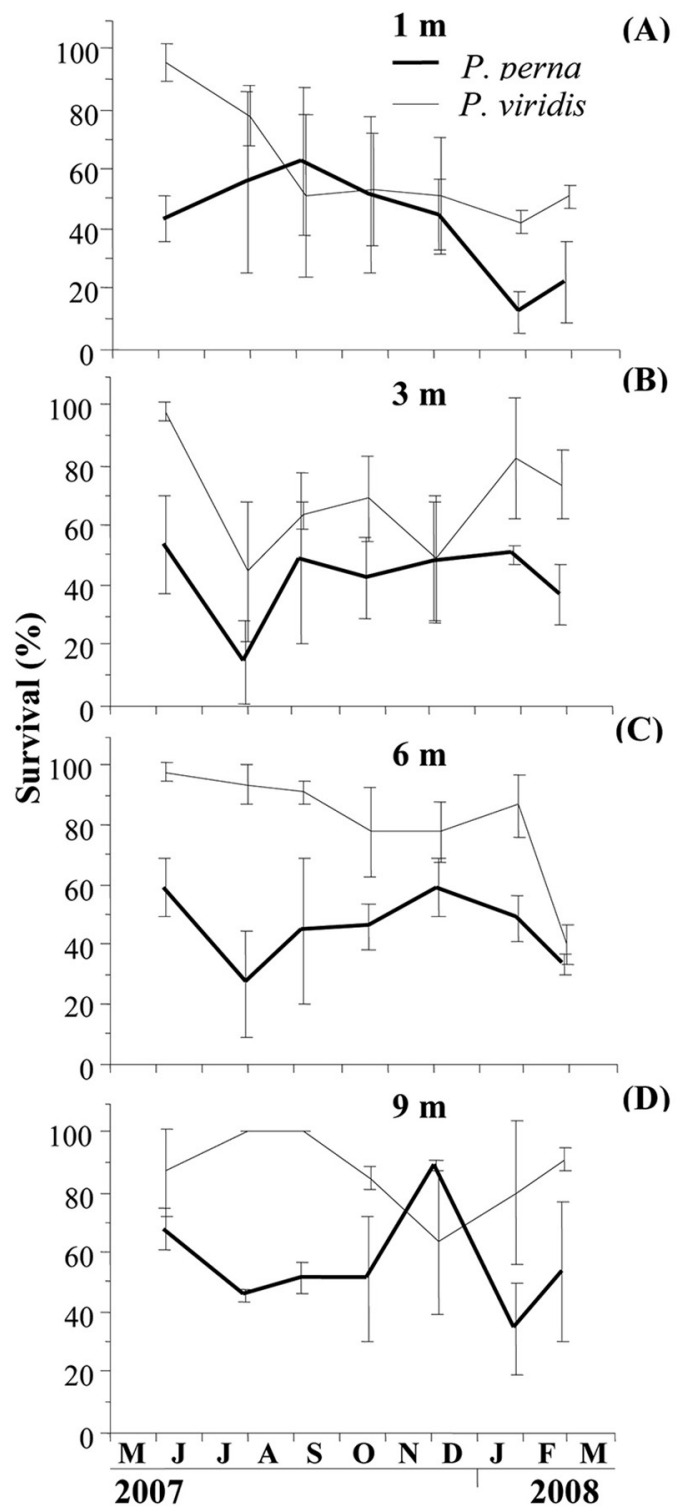

Figure 6. Variation of survival of $P$. perna and $P$. viridis grown at $1 \mathrm{~m}$ (A), $3 \mathrm{~m}$ (B), $6 \mathrm{~m}$ (C) and $9 \mathrm{~m}$ (D).

only the PIM (inversely) and Culture depth (positively) participated in the explanation of the variance of survival of up to $54.7 \%$.

\section{DISCUSSION}

The relatively lower variability reported for the environmental factors as between water column depths might be a consequence of the fact that the maximum culture depth in the present study was limited by the seabed $(13 \mathrm{~m})$. Therefore, the present depth range considered here (1-9 m) corresponds to the euphotic zone, dominated by the highest concentrations of phytoplankton biomass (FERRÁZ-REYES, 1989).

The growth of both mussel species was influenced by both the upwelling and water stratification periods which are characteristic of northeastern Venezuela. This was markedly evidenced during the slow growth period of the mussels in the stratification period, especially for P. perna (August 2007 to November 2007), most likely associated with high temperatures and low food availability. This period is critical in northeastern Venezuela due to its negative influence on the development of organisms by their increased metabolism (high temperature) associated with a low food availability that prevents bivalves from fully counteracting their metabolic demands (LODEIROS; HIMMELMAN, 2000; FREITES et al., 2003). In this sense, LODEIROS et al. (2001) noted a negative influence of higher temperature and scarce food availability on the growth of the scallops Nodipecten nodosus and Euvola ziczac cultured in the Gulf of Cariaco. This was probably influenced by a complex environmental variability due to the presence and absence of coastal upwelling that would stress the animals, particularly during the period dominated by a recession of coastal upwelling (high temperatures and low food availability).

Stepwise models showed that the availability of food (POM) was the factor that positively explained the observed variance of growth for both mussel species. Yet, at the end of the study, the length and mass of $P$. perna were significantly higher than $P$. viridis. This suggests that $P$. perna can achieve higher efficiency by exploiting food sources in the water column to accelerate its growth rate, especially in periods with higher availability of food. On the other hand, P. viridis showed a relatively low response to these environmental changes and maintained a sustained but slow growth. Similarly, in a comparative study of the growth of both species in suspended culture in the Gulf of Cariaco by ACOSTA et al. (2010), it was reported that the presence of the high-energy biochemical substrates reported in $P$. perna relative to $P$. viridis could be because $P$. perna exploits the food present in the water column more efficiently. This suggests that this species has a more efficient food collection system than $P$. viridis under conditions of suspended culture.

Temperature was associated inversely with all growth parameters, except shell length. Low temperatures are especially observed during the seasonal upwelling in the area, leading to greater food availability (phytoplankton biomass and organic matter). In contrast, high temperatures 
Table 2. Multiple regression analysis (Stepwise) of the relationship of environmental factors and the growth and survival of $P$. perna grown at depths of $1,3,6$, and $9 \mathrm{~m}$ in suspended culture from May/07 to March/08.

\begin{tabular}{|c|c|c|c|c|c|c|}
\hline P. perna & Parameters & Coefficients & $\mathrm{SE}$ & F-ratio & $P$ & $r^{2}$ \\
\hline \multirow{3}{*}{ Shell mass } & Constant & 23.153 & 8.809 & 39.143 & 0.001 & 0.555 \\
\hline & POM & 2.151 & 0.344 & 10.867 & 0.01 & 0.676 \\
\hline & Temperature & -1.074 & 0.326 & & & \\
\hline \multicolumn{7}{|c|}{$r^{2}=0.676 ; n=32 ; \mathrm{F}_{2,29}=30.249 ; P=0.001$} \\
\hline \multirow{3}{*}{ Tissue mass } & Constant & 7.791 & 0.127 & 40.038 & 0.001 & 0.503 \\
\hline & POM & 0.484 & 0.076 & 26.324 & 0.001 & 0.740 \\
\hline & Temperature & -0.372 & 0.072 & & & \\
\hline \multicolumn{7}{|c|}{$r^{2}=74.0 ; n=32 ; \mathrm{F}_{2,29}=41.185 ; P=0.001$} \\
\hline \multirow[t]{2}{*}{ Shell Length } & Constant & 32.135 & 3.649 & 43.509 & 0.001 & 0.602 \\
\hline & POM & 4.179 & 0.634 & & & \\
\hline \multicolumn{7}{|c|}{$r^{2}=0.592 ; n=32 ; \mathrm{F}_{1,30}=43.509 ; P=0.001$} \\
\hline \multirow{4}{*}{ Survival } & Constant & -9.028 & 27.343 & 21.336 & 0.001 & 0.214 \\
\hline & PIM & -4.193 & 0.908 & 18.675 & 0.001 & 0.355 \\
\hline & Oxygen & 18.274 & 4.229 & 14.519 & 0.001 & 0.575 \\
\hline & Cult. DepthxChlorop & 1.000 & 0.263 & & & \\
\hline \multicolumn{7}{|c|}{$r^{2}=0.575 ; n=32 ; \mathrm{F}_{43,28}=12.639 ; P=0.001$} \\
\hline
\end{tabular}

Chlorop: Chlorophyll $a$; POM: Particulate organic matter; PIM: particulate inorganic matter; Culture depth: Cult. depth.

Table 3. Multiple regression analysis (Stepwise) of the relationship of environmental factors and the growth and survival of $P$. viridis grown at depths of $1,3,6$, and $9 \mathrm{~m}$ in suspended culture from May/07 to March/08.

\begin{tabular}{|c|c|c|c|c|c|c|}
\hline$P$. viridis & Parameters & Coefficients & SE & $F$-ratio & $P$ & $r^{2}$ \\
\hline \multirow[t]{3}{*}{ Shell mass } & Constant & 12.413 & 5.457 & 51.652 & 0.001 & 0.625 \\
\hline & POM & 1.531 & 0.213 & 8.558 & 0.01 & 0.711 \\
\hline & Temperature & -0.591 & 0.202 & & & \\
\hline \multicolumn{7}{|c|}{$r^{2}=0.711 ; n=32 ; F_{2,29}=35.637 ; P=0.001$} \\
\hline \multirow[t]{3}{*}{ Tissue mass } & Constant & 3.008 & 1.228 & 21.161 & 0.001 & 0.422 \\
\hline & POM & 0.219 & 0.048 & 9.763 & 0.01 & 0.568 \\
\hline & Temperature & -0.141 & 0.045 & & & \\
\hline \multicolumn{7}{|c|}{$r^{2}=0.568 ; n=32 ; F_{2,29}=19.037 ; P=0.001$} \\
\hline \multirow[t]{2}{*}{ Shell length } & Constant & 27.991 & 2.631 & 81.833 & 0.001 & 0.732 \\
\hline & POM & 4.132 & 0.457 & & & \\
\hline \multicolumn{7}{|c|}{$r^{2}=0.732 ; \mathrm{n}=32 ; F_{1,30}=81.833 ; P=0.001$} \\
\hline \multirow[t]{3}{*}{ Survival } & Constant & 88.568 & 8.999 & 22.358 & 0.001 & 0.310 \\
\hline & PIM & -2.965 & 0.627 & 15.136 & 0.001 & 0.547 \\
\hline & Cult. depth & 8.715 & 2.240 & & & \\
\hline \multicolumn{7}{|c|}{$r^{2}=0.547 ; n=32 ; F_{2,29}=17.502 ; P=0.001$} \\
\hline
\end{tabular}

were observed between August and November 2007, which coincided with a decrease in growth rates of the animals, being more evident in the mass of soft tissues of P. perna.

The growth of neither mussel species was related to the cultivation depth; in contrast survival was positively and significantly related to depth, which may explain in part how $P$. viridis attained greater growth at the depth with a greater availability of organic matter $(9 \mathrm{~m}$, closest to the seabed), especially during the period of low food availability of phytoplanktonic origin between August 2007 and November 2007. This suggests a capacity of this mussel species for taking advantage of this food source. ACOSTA et al. (2012) demonstrated the potential of this 
species for bottom culture, obtaining higher yields, even greater than those achieved in suspension culture with $P$. perna, suggesting the possibility of bottom culture in areas of high availability of organic matter such as mangrove systems. LODEIROS; HIMMELMAN (2000) noted that the growth rates of bivalves depend on the quality, nature and availability of seston. When PIM is high, dilution of the organic fraction or particulate organic matter (POM) occurs, thus reducing the availability of nutrients for bivalves. The inverse association of survival and PIM (see Table 1) suggests that both species are sensitive to the PIM/POM ratio.

A factor linked to the culture methods is biofouling. This should always be monitored in studies on culture feasibility of marine bivalves since it could have a negative effect on mussel growth, limiting the opening of the valves and decreasing the absorption of nutrients (LODEIROS; HIMMELMAN, 2000). In the present study, the incidence of biofouling began in September 2007, being higher in P. perna, but only became significant in January 2008. However, this factor does not appear to have a negative influence on growth rates because it was not observed in either of the models predicted by multivariate analysis.

In the case of the variance observed in the soft tissue mass, the equation model showed that this variance was related positively to $\mathrm{POM}$ and inversely to temperature, confirming that food availability and temperature are the most influential factors in the good condition of bivalves (BAYNE; NEWELL, 1983; MACDONALD; THOMPSON, 1985; MALACHOWSKI, 1988; JARAMILLO et al., 1993; LODEIROS; HIMMELMAN, 2000; ARRIECHE et al., 2002). Regarding POM as a food source for mussels, this aspect can be attributed to that described by CRANFORD and GRAND (1990), that although the phytoplankton is an important source of food, organic seston is an alternative energy source for bivalves. However, although chlorophyll $a$ is not considered by the analysis to explain significantly the observed variance in either growth or survival parameters, it is clear that growth is triggered at the end of the study period, especially in the months of January, February and March. At this time, chlorophyll $a$ increased as a result of the initiation and development of the upwelling period, suggesting that it is an important factor for the growth values observed in this period too. In fact, chlorophyll a proved to be a significant and positive factor when the Stepwise analysis did not take into account the seston (PIM and POM), increasing the explained variability between 35 and $40 \%$ in some of the biometric variables of both mussels. This could be due to the major linear importance of the POM variable in this specific analysis that varied between 42 and $73 \%$, (see Tables 2 and 3 ). In this sense, several studies have shown that the differences in the biochemical composition of mussel populations located in zones with distinct environmental conditions were due to qualitative and/or quantitative differences in the food availability of phytoplanktonic origin (PÉREZ-CAMACHO et al., 1995; FERNÁNDEZ-REIRIZ et al., 1996; OKUMUS; STIRLING, 1998).

In order to increase production values of both mussel species, and taking into count the results obtained in this study, higher growth rate values of all biometric parameters for both species were obtained at depths below $6 \mathrm{~m}$. Moreover, survival rates were positively related to the depth of cultivation which allows us to suggest that the artefacts or gear used for cultivation should be placed below 6-8 $\mathrm{m}$ deep.

\section{CONCLUSIONS}

Environmental factors exercise an influence on the growth patterns of both species cultivated in suspension. The factors that showed greater effects on the growth of the mussel species were availability of food (POM) and temperature.

Greater and faster growth was obtained for P. perna than for P. viridis; the latter mussel species seemed to be under stress during suspended culture.

Mussel species and culture depth factors have a significant influence on growth rates and survival of both mussels, demonstrating that the performance of both species depends significantly on these factors.

\section{ACKNOWLEDGEMENTS}

We are grateful to "Mission Science" for providing an MSc scholarship for Marielyn García. We also wish to thank: the Instituto Socialista de la Pesca y Acuicultura of Venezuela (INSOPESCA) for allowing the undertaking of this study; the fishing community at La Fragata for their support during fieldwork, and Andrew Dale (GEOMAR, Germany) for improving the English-language manuscript.

\section{REFERENCES}

ACOSTA, V.; LODEIROS, C.; PRIETO, A.; GLEM, M.; NATERA, Y. Efecto de la profundidad sobre el crecimiento de los mejillones Perna perna y Perna viridis (Bivalvia: Mytilidae) en cultivo suspendidoen el Golfo de Cariaco, Venezuela. Zootecnia Trop., v. 27, n. 3, p. 315-328, 2009. 
ACOSTA, V.; NATERA, Y.; LODEIROS, C.; FREITES, L; VÁSQUEZ, A. Componentes bioquímicos de los tejidos de Perna perna y P. viridis (Lineo, 1758) (Bivalvia: Mytilidae), en relación al crecimiento en condiciones de cultivo suspendido. Lat. Amer. J. Aquat. Res., v. 38, n. 1, p. 37-46, 2010.

ACOSTA, V.; MONTES, M.; CORTEZ, R.; GUEVARA, M.; LODEIROS, C. Crecimiento del mejillón verde Perna viridis (Bivalvia: Mytilidae) bajo sistema de cultivo de fondo en la ensenada de Turpialito, Golfo de Cariaco, Venezuela. Rev. Biol. Trop., v. 60, n. 4, p. 1749-1762, 2012.

APPUKUTTAN, K. K.; MOHAMED, K. S.; KRIPA, V.; ASHOKAN, P. K.; ANIL, M. K.; SASIKUMAR, G.; VELAYUDHAN, T. S.; LAXMILATHA, P.; KOYA, K. P. S.; RADHAKRISHNAN, P.; JOSEPH, M.; ALLOYCIOUS, P. S.; SURENDRANATHAN, V. G.; SIVADASAN, M. P.; NAGARAJA, D.; JENNI, B.; NAIK, M. S. Survey of green mussel seed resources of Kerala and Karnataka. Mar Fisher. Inform. Serv. Tech. Ext. Ser., v. 168, p. 12-19, 2001.

ARRIECHE, D.; LICET, B.; GARCÍA, N.; LODEIROS, C.; PRIETO, A. Índice de condición, gonádico y de rendimiento del mejillón marrón Perna perna (Bivalvia: Mytilidae), del Morro de Guarapo, Venezuela. Interciencia. v. 27, n. 11, p. 613-619, 2002.

BAUTISTA C. Moluscos: Tecnología de Cultivo. Madrid: Mundi-Prensa, 1989. $167 \mathrm{p}$.

BAYNE, B. L.; NEWELL, R. C. Physiological energetic of marine molluscs. In: SALEUDDIN, A. S. M.; WILBUR, K. M. (Eds). The Mollusca. New York: Academic Press, 1983. p. 407-515.

CARMICHAEL, R. H.; SHRIVER, A. C.; VALIELA, I. Changes in shell and soft tissue growth, tissue composition, and survival of quahogs, Mercenaria mercenaria, and softshell clams, Mya arenaria, in response to eutrophic-driven changes in food Population biology and secondary production of the stout razor clam on a sandflat supply and habitat. J. Exp. Mar. Biol. Ecol., v. 313, n. 1, p. 75-104, 2004.

CRANFORD, P. J.; GRAND, J. Particle clearance and absorption of phytoplankton and detritus by the sea scallop Placopecten magellanicus (Gmelin). J. Exp. Mar. Biol. Ecol., v. 137, n. 2, p. $105-121,1990$.

CRANFORD, P. J.; HILL, P. S. Seasonal variation in food utilization by the suspension-feeding bivalve mollusks Mytilus edulis and Placopecten magellanicus. Mar. Ecol. Prog. Ser., v. 190, p. 223-239, 1999.

DRAPEAU, A.; COMEAU, L. A.; LANDRY, T.; STRYHN, H.; DAVIDSON, J. Association between long line design and mussel productivity in Prince Edward Island, Canada. Aquaculture, v. 261, n. 3, p. 879-889, 2006.

ELLIS, K.; GIBERSON, G.; DAVIDSON, J. Marine organisms associated with mussel socks on Prince Edward Island: A manual for mussel growers. Charlottetown: Document Publishing Centre, 2002. 55 p.

FERNÁNDEZ-REIRIZ, M. J.; LABARTA, U.; BABARRO, J. M. F. Comparative allometries in growth and chemical composition of mussel (Mytilus galloprovincialis Lmk) cultured in two zones in the ria Sada (Galicia, NW Spain). J. Shell. Res., v. 15, n. 2, p. 349-353, 1996.

FERRÁZ-REYES, E. Influencia de los factores físicos en la distribución vertical de la biomasa fitoplanctónica en el golfo de Cariaco (Venezuela). Bol. Inst. Oceanogr., v. 28, n. 1-2, p. 47-56, 1989 .
FREITES, L.; LODEIROS, C.; GUEVARA, M.; ALIÓ, J.; GRAZIANI, C. Experiencias en el cultivo de organismos marinos en el Golfo de Cariaco, Venezuela. Saber, v. 24, n. 1, p. 5-24, 2012.

FREITES, L.; LODEIROS, C. J.; NARVÁEZ, N.; ESTRELLA, G.; BABARRO, J. M. F. Growth and survival of the scallop Lyropecten (= Nodipecten) nodosus (L., 1758) in suspended culture in the Cariaco Gulf (Venezuela), during a nonupwelling period. Aquac. Res., v. 34, n. 9, p. 709-718, 2003.

GALLARDO, W.; SAMONTE, G.; ORTEGA, R. Raft culture of green mussel Perna viridis in Sapian Bay, Philippines. J. Shell. Res., v. 11, p. 195-196, 1992.

GRIFFITHS, C. L.; GRIFFITHS, R. J. Bivalvia. In: PANDIAN, J. H.; VERNBERG, F. J. (Eds.). Animals Energetics. New York: Academy Press, 1987. p. 1-88.

HAWKINS, A. J. S.; FANG, J. G.; PASCOE, P. L.; ZHANG, J. H.; ZHANG, X. L.; ZHU, M. Y. Modelling short-term responsive adjustments in particle clearance rate among bivalve suspension-feeders: separate unimodal models of seston volume and composition in the scallop Chlamys farreri. J. Exp. Mar. Biol. Ecol., v. 261, n. 1, p. 61-73, 2001.

JARAMILLO, R.; WINTER, J.; VALENCIA, J.; RIVERA, A. Gametogenic cycle of the chiloe scallop (Chlamys amandi). J. Shell. Res., v. 12, n. 1, p. 59-64, 1993.

LODEIROS, C.; HIMMELMAN, J. Identification of factors affecting growth and survival of the tropical scallop Euvola (Pecten) ziczac in the Golfo de Cariaco, Venezuela. Aquaculture, v. 182, p. 91-114, 2000.

LODEIROS, C.; MAEDA-MARTÍNEZ, A.; FREITES, L.; URIBE, E.; LLUCH-COSTA, D.; SICARD, M. T. Ecofisiología de Pectínidos. In: MAEDA-MARTÍNEZ, A. (Ed.). Los Moluscos Pectínidos de Iberoamérica: Ciencia y Acuicultura. México: Limusa, 2001. p. 77-88.

MACDONALD, B. A.; THOMPSON, R. J. Influence of temperature and food availability on the ecological energetic of the giant scallop Placopecten magellanicus. II. Reproductive output and total production. Mar. Ecol. Prog. Ser., v. 25, p. 295-303, 1985.

MACNAIR, N. Invasive Tunicates of Concern for Prince Edward Island Aquaculture. Aqua Info Aquaculture Note. Charlottetown: Department of Agriculture Fisheries and Aquaculture, 2005.

MALACHOWSKY, M. The reproductive cycle of the rock scallop Hinnites giganteus (Grey) in Humboldt Bay, California. J. Shell. Res., v. 7, p. 341-348, 1988.

MANDELLI, E.; FERRÁZ-REYES, E. Primary production and phytoplankton dynamics in a tropical inlet, Gulf of Cariaco, Venezuela. Intern. Int. Rev. Ges. Hydrobiol., v. 57, p. 85-95, 1982.

MILOSLAVICH, P.; KLEIN, E. Ecorregiones marinas del Caribe venezolano. En: Klein, E. (Ed). Prioridades de PDVSA en la conservación de la biodiversidad en el Caribe venezolano. Petróleos de Venezuela, S.A. Caracas: Universidad Simón Bolívar. The Nature Conservancy. p. 72, 2008.

NAIR, M. R.; APPUKUTTAN, K. K. Effect of temperature on the development, growth, survival and settlement of green mussel Perna viridis (Linnaeus, 1758). Aquac. Res., v. 34, n. 12, p. 1037-1045, 2003.

NAVARRO, J. M.; THOMPSON, R. J. Seasonal fluctuations in the size spectra, biochemical composition and nutritive value of the seston available to a suspension-feeding bivalve in a subarctic environment. Mar. Ecol. Prog. Ser., v. 125, p. 95-106, 1995. 
OKUMUS, I.; STIRLING, H. P. Seasonal variations in the weight, condition index and biochemical composition of mussels (Mytilus edulis, L.) in suspended culture in two Scottish sea lochs. Aquaculture, v. 159, n. 3-4, p. 249-261, 1998.

PÉREZ-CAMACHO, A.; LABARTA, U.; BEIRAS, R. Growth of mussels (Mytilus edulis galloprovincialis) on cultivation rafts: influence of seed source, cultivation site and phytoplankton availability. Aquaculture, v. 138, p. 349-362, 1995.

PRIETO, A. S.; VÁSQUEZ, M.; RUÍZ, L. J. Dinámica energética del crecimiento en una población del mejillón Perna perna (Filibranchia: Mytilidae) en el noreste del estado Sucre, Venezuela. Rev. Biol. Trop., v. 47, n. 3, p. 399-410, 1999.

RAJAGOPAL, S.; VENUGOPALAN, V. P.; NAIR, K. V. K.; VAN DER VELDE, G.; JENNER, H. A.; HARTOG, C. D. Reproduction, growth rate and culture potential of the green mussel, Perna viridis (L) in Edaiyur backwaters, east coast of India. Aquaculture, v. 162, n. 3-4, p.187-202, 1998.

RAJAGOPAL, S.; VENUGOPALAN, V. P.; VAN DER VELDE, G.; JENNER, H. A. Greening of the coasts: a review of the Perna viridis success story. Aquat. Ecol., v. 40, n. 3, p. 273297, 2006.

RYLANDER, K.; PÉREZ, J.; GÓMEZ, J. The distribution of the brown mussel Perna perna and the green mussel Perna viridis (Mollusca: Bivalvia: Mytilidae) in northeast Venezuela. Caribb. Mar. Stud., v. 5, p. 86-87, 1996.

RIVONKER, C. U.; ANSARI, Z. A.; PARULEKAR, A. H. Cultivation of green mussel Perna viridis L., on a floating raft in an estuary along the west coast of India. Aquaculture, v. 112 , n. 1 , p. $47-56,1993$.

SEGNINI, M.; CHUNG, K. S.; PÉREZ, J. E. Salinity and temperature tolerances of the green and brown mussels, Perna viridis and Perna perna (Bivalvia: Mytilidae). Rev. Biol. Trop., v. 46, p. 121-125, 1998.

SEGNINI, M. Influence of salinity on the physiological conditions in mussels, Perna viridis and Perna perna (Bivalvia: Mytilidae). Rev. Biol. Trop., v. 51, p. 153-158, 2003.
SOKAL, R. R.; ROLHF, F. Biometría: Principios y métodos estadísticos en la investigación biológica. Madrid: H. Blumé, 1979. $832 \mathrm{p}$.

SREENIVASAN, P. V.; THANGAVELU, R.; POOVANNAN, P. Biology of the green mussel, Perna viridis (Linnaeus) cultured in Muttukadu lagoon, Madras. Indian J. Fish., v. 36, n. 2, p. 149-155, 1989.

STRICKLAND, J. D. H.; PARSON, T. R. A practical handbook of sea water analysis. Bull. Fish. Res. Board Canada, v. 167, p. 1-310, 1972.

THOMPSON, B.; MACNAIR, N. An Overview of the Clubbed Tunicate (Styela clava) in Prince Edward Island. Prince Edward Island Depart. Agric. Fish. Aquac. For. Tech. Rep., v. 234, p. 29, 2004.

THOMPSON, R. J.; MACDONALD, B. A. Physiological integrations and energy partitioning. In: SHUMWAY, S. E.; PARSONS, G. J. (Eds.). Scallops: Biology. Ecology and Aquaculture. Developments in Aquaculture and Fisheries Science. Amsterdam: Elsevier Science, 1991. p. 347-376.

VARELA，R.; CARVAJAL，F.; MÜLLER-KARGER，F. El fitoplancton en la plataforma nororiental de Venezuela. In: FRÉON, P.; MENDOZA, J. (Eds.). La sardina (Sardinella aurita). Su medio ambiente y explotación en el Oriente de Venezuela. Paris: IRD, 2003. p. 263-294.

VELASCO, L. A.; NAVARRO, J. M. Feeding physiology of infaunal (Mulinia edulis) and epifaunal (Mytilus chilensis) bivalves under a wide range of concentrations and qualities of seston. Mar. Ecol. Prog. Ser., v. 240, p. 143-155, 2002.

VIÑOLES, I.; SEGNINI, M.; BRACHO, M.; CHUNG, K. Efecto de la temperatura de aclimatación sobre el crecimiento instantáneo de Perna viridis (Bivalvia: Mytilidae), según el coeficiente ARN/ADN. Rev Biol. Trop., v. 48, n. 1, p. 159170,2000

WAITE, L.; GRANT, J.; DAVIDSON, J. Bay-scale spatial growth variation of mussels Mytilus edulis in suspended culture, Prince Edward Island, Canada. Mar. Ecol. Prog. Ser., v. 297, p. $157-167,2005$. 
